$\begin{array}{ll}\text { Volume } & : 04 \\ \text { Nomor } & : 02 \\ \text { Bulan } & : \text { Mei } \\ \text { Tahun } & : 2018 \\ \text { http } & : \text { //ejurnal.pps.ung.ac.id/index.php/AKSARA/index }\end{array}$

\title{
Penerapan Reward and Punishment dalam Upaya Peningkatan Disiplin Kehadiran Mengajar Guru Di SDN 03 Duhiadaa
}

\author{
Rapi Monoarfa \\ SDN 03 Duhiadaa Kabupaten Pohuwato \\ rapimonoarfa@gmail.com
}

\begin{abstract}
Abstrak
Penelitian ini bertujuan ingin mencari alternatif pemecahan masalah sebagai upaya meningkatkan disiplin guru dalam kehadiran mengajar dikelas melalui penerapan Reward and Punishment. Penelitian tindakan ini dilakukan oleh Kepala sekolah pada guru - guru di SDN 03 Duhiadaa Kabupaten Pohuwato pada tahun pelajaran 2016/2017. Rancangan penelitian yang digunakan adalah rancangan penelitian tindakan sekolah yang alurnya, yaitu membuat siklus yaitu dari rencana tindakan, melaksanakan tindakan, observasi dan refleksi pelaksanaan tindakan selama dua siklus. Hasil refleksi tersebut digunakan sebagai pedoman untuk pengambilan keputusan mengambil keputusan melanjutkan atau menghentikan penelitian. Penelitian ini dilaksanakan dalam dua siklus, karena dari hasil penelitian dan analisa data, ternyata pada siklus kedua, kedisiplinan guru dalam kehadiran dikelas pada proses belajar mengajar meningkat dan memenuhi indikator yang telah ditetapkan sebesar 75\%. Dari hasil penelitian ini, dapat disimpulkan bahwa untuk meningkatkan disiplin guru dalam kehadiran dikelas pada kegiatan belajar mengajar dapat dilakukan dengan penerapan Reward and Punishment kepada guru. Kata Kunci : Disiplin Guru, Reward and Punishment
\end{abstract}

\section{Pendahuluan}

Pendidikan adalah sesuatu yang essensial / penting di dalam kehidupan. Baik itu kehidupan berbangsa dan bernegara, bermasyarakat ataupun dalam kehidupan berkeluarga. Banyak faktor yang mempengaruhi keberhasilan dalam dunia pendidikan. Faktor tersebut antara lain adalah kurikulum, sarana prasarana, input siswa dan terutama faktor tertentu dari keberhasilan tersebut adalah guru sebagai tenaga pendidik

Guru adalah suatu sebutan bagi jabatan, posisi, dan profesi bagi seseorang yang mengabdikan dirinya dalam bidang pendidikan melalui proses edukatif secara terpola, formal, dan sistematis Guru adalah pendidik profesional dengan tugas utama mendidik dan mengevaluasi peserta didik, pada pendidikan anak usia dini jalur pendidikan formal, pendidikan dasar dan pendidikan menengah. Untuk meningkatkan peranan guru dalam proses belajar mengajar dan hasil belajar siswa, maka guru diharapkan mampu menciptakan lingkungan belajar yang efektif dan akan mampu mengelola kelas.

Keberhasilan proses pembelajaran sangat bergantung pada beberapa faktor diantaranya adalah faktor guru. Guru sangat memegang peranan penting dalam keberhasilan proses pembelajaran. Guru yang mempunyai kompetensi yang baik tentunya akan sangat mendukung keberhasilan proses pembelajaran. Guru yang mempunyai kompetensi yang baik tentunya akan sangat mendukung keberhasilan proses pembelajaran. Peranan guru selain sebagai seorang pengajar, guru juga 


$\begin{array}{ll}\text { Volume } & : 04 \\ \text { Nomor } & : 02 \\ \text { Bulan } & : \text { Mei } \\ \text { Tahun } & : 2018 \\ \text { http } & : / / \text { jurnal.pps.ung.ac.id/index.php/AKSARA/index }\end{array}$

berperan sebagai seorang pendidik. Keteladanan guru dapat dilihat dari prilaku guru sehari-hari baik didalam sekolah maupun diluar sekolah. Selain keteladanan guru, kedisiplinan guru juga menjadi salah satu hal penting yang harus dimiliki oleh guru sebagai seorang pengajar dan pendidik.

Kurang maksimalnya disiplin dikalangan guru yang cukup memprihatinkan adalah perihal kedatangan guru di sekolah. Sebagai seorang pegawai negeri yang sudah menerima hak finansial secara penuh, wajib melaksanakan tugas dan kewajibannya. Termasuk kewajibannya untuk mentaati peraturan atau tata tertib yang berlaku di sekolah. Kedisiplinan guru dalam melaksanakan tugas merupakan suatu hal yang belum dapat diselesaikan permasalahannya secara maksimal terutama jam masuk sekolah di sekolah-sekolah yang berada di pedesaan. Faktor jarak dan lokasi sekolah menjadi beberapa alasan keterlambatan. Keterlambatan guru masuk ke sekolah menggambarkan belum terbentuknya sikap guru yang berkualitas dan profesional.

Selama ini yang terjadi di lapangan adalah seringnya kelas kosong saat jam belajar. Ini dikarenakan guru tidak masuk kelas dan tanpa ada tugas yang harus dikerjakan siswa. Ketidak masukan guru itu bisa saja karena kepentingan dinas atau yang lain. Ketidak tepatan dalam hal guru masuk kelas sehingga jeda waktu pergantian jam bisa dimanfaatkan siswa untuk melakukan tindakan indisipliner. Komitmen guru dalam hal ini kadang sering menjadi penyebabnya

Oleh karena itu salah satu cara penerapan disiplin dapat ditegakkan yaitu melalui pemberian reward and punishment. Reward dan punishment merupakan dua bentuk metode dalam memotivasi seseorang untuk melakukan kebaikan dan meningkatkan prestasinya (Nugroho,2006). Reward artinya ganjaran, hadiah, penghargaan atau imbalan. Dalam konsep manajemen, reward merupakan salah satu alat untuk peningkatan motivasi para pegawai. Punishment merupakan hukuman atau konsekuensi yang harus dipertanggungjawabkan seseorang karena tidak melakukan kewajibannya

Kedua metode ini sudah cukup lama dikenal dalam dunia kerja. Tidak hanya dalam dunia kerja, dalam dunia pendidikan pun kedua ini kerap kali digunakan. Penerapan reward dan punishment dalam dunia pendidikan dapat diterapkan sepanjang hal tersebut tidak bertentangan dengan tujuan pendidikan itu sendiri. Penerapan reward dan punishment juga tidak hanya diterapkan kepada siswa yang berprestasi atau yang melanggar tata tertib, tetapi juga dapat diterapkankepada guru - guru agar mereka berdisiplin dalam mengajar untuk memenuhi tugas mereka memberikan pelajaran kepada siswanya.

Berdasarkan uraian tersebut penulis tertarik untuk melakukan penelitian tindakan sekolah dengan judul : "Penerapan Reward And Punishment Dalam Upaya Peningkatan Disiplin Kehadiran Mengajar Guru Di SDN 03 Duhiadaa”

\section{Kajian Pustaka}

\section{Pengertian Disiplin Kerja}

Kedisiplinan berasal dari kata disiplin yang mendapat awalan ke dan akhiranan. Disiplin menurut bahasa berasal dari kata "Discipline" yang artinya kedisiplinan. Kedisiplinan adalah kepatuhan untuk menghormati dan melaksanakan suatu sistem yang mengharuskan orang untuk tunduk kepada keputusan, perintah 


$\begin{array}{ll}\text { Volume } & : 04 \\ \text { Nomor } & : 02 \\ \text { Bulan } & : \text { Mei } \\ \text { Tahun } & : 2018 \\ \text { http } & : \text { //ejurnal.pps.ung.ac.id/index.php/AKSARA/index }\end{array}$

dan peraturan yang berlaku. Dengan kata lain, disiplin adalah sikap menaati peraturan dan ketentuan yang telah ditetapkan tanpa pamrih

Menurut Sulistyowati (2012:30) disiplin adalah tindakan yang menunjukkan perilaku tertib dan patuh pada berbagai ketentuan dan peraturan. Menurut Elfindri, dkk (2012:102) orang yang disiplin adalah orang yang teguh didalam memegang aturan, misalnya disiplin didalam pekerjaannya yang terlihat dari masuk dan keluar tepat waktu, senantiasa mengikuti norma dan peraturan yang berlaku. Menurut Poerwadarminta (Unaradjan, 2003:9) disiplin adalah latihan watak dan batin agar segala perbuatan seseorang sesuai dengan peraturan yang ada.

Pengertian disiplin dari beberapa ahli dapat disimpulkan yaitu suatu tindakan latihan watak dan batin yang menunjukkan keteguhan berperilaku tertib dan patuh pada berbagai peraturan dan norma yang berlaku baik ketika berada di sekolah maupun di dalam lingkungan masyarakat. Disiplin yang diterapkan seseorang akan berdampak baik dari dalam diri seseorang karena dapat menjadikan diri seseorang menjadi seorang yang berguna untuk diri sendiri dan orang lain

Kemudian dalam Kamus Lengkap Bahasa Indonesia pengertian kerja adalah "perbuatan melakukan sesuatu kegiatan yang bertujuan mendapatkan hasil; hal pencarian nafkah". Dari definisi tersebut dapat pula diartikan bahwa kerja adalah fungsi hidup manusia untuk mendapatkan kebahagiaan lahir dan batin. Manusia bekerja adalah untuk menghasilkan suatu alat pemuas kebutuhannya.

Bila kedua kata tersebut yaitu kata "disiplin" dan kata "kerja" digabungkan, maka disiplin kerja dapat dapat bermakna suasana batin yang berupa perasaan senang atau tidak senang, bergairah atau tidak bergairah, dan bersemangat atau tidak bersemangat dalam melakukan suatu pekerjaan.

Disiplin kerja merupakan salah satu faktor yang dapat mempengaruhi produktifitas kerja, sedangkan produktifitas merupakan keberhasilan dari suatu organisasi. Dengan demikian terdapat keterkaitan antara disiplin kerja dengan produktifitas. Sehingga dapat dikatakan bahwa disiplin adalah salah satu penentu berhasil atau tidaknya tujuan organisasi.

Dapat disimpulkan bahwa disiplin kerja guru adalah suatu ketaatan serta kepatuhan seorang pendidik dalam menjalankan segala peraturan atau tata tertib yang telah diberlakukan di sekolah dengan penuh kesadaran dari dalam dirinya. Karena guru merupakan salah satu kunci keberhasilan dalam proses pembelajaran di kelas.

Guru memiliki pengaruh yang cukup besar terhadap proses pembelajaran dan perilaku para siswanya. Jika para guru dapat bersikap disiplin terhadap tata tertib yang ada di sekolah, maka cenderung para siswa pun akan meniru sikap disiplin para gurunya tersebut. Dengan membiasakan diri untuk bersikap disiplin, maka diharapkan akan menumbuhkan rasa tanggung jawab dalam melaksanakan tugas yang diembannya dan dapat mewujudkan suasana pembelajaran yang baik

\section{Hakekat Reward Dan Punishment}

Reward berasal dari bahasa Inggris yang artinya hadiah, ganjaran, penghargaan atau imbalan. Reward sebagai alat pendidikan diberikan ketika siswamelakukan sesuatu yang baik. Menurut Djamarah (2008: 182), reward (hadiah) adalah memberikan sesuatu kepada orang lain sebagai penghargaan atau 


$\begin{array}{ll}\text { Volume } & : 04 \\ \text { Nomor } & : 02 \\ \text { Bulan } & : \text { Mei } \\ \text { Tahun } & : 2018 \\ \text { http } & : \text { //ejurnal.pps.ung.ac.id/index.php/AKSARA/index }\end{array}$

kenang - kenangan/cenderamata. Hadiah yang diberikan kepada orang lain berupa apa saja, tergantung dari keinginan pemberi. Bentuk reward yang lain juga bias disesuaikan dengan prestasi yang dicapai oleh seseorang. Semua orang berhak menerima hadiah dari seseorang dengan motif - motif tertentu

Menurut Slameto (2010: 171), reward merupakan suatu penghargaan yang diberikan guru kepada siswa sebagai hadiah karena siswa tersebut telah berperilaku baik dan sudah berhasil melaksanakan tugas yang diberikan guru dengan baik. Purwanto (2011: 182) mengatakan reward adalah alat untuk mendidik anak - anak supaya anak merasa senang karena perbuatan atau pekerjaannya mendapat penghargaan. Sejalan dengan itu Hamalik (2009: 184) mengatakan bahwa reward memiliki tujuan untuk membangkitkan atau mengemban minat, reward ini hanya berupa alat untuk membangkitkan minat saja bukanlah sebagai tujuan. Tujuan pemberian penghargaan dalam belajar adalah bahwa seseorang akan menerima penghargaan setelah melakukan pembelajaran dengan baik dan akan melakukan pembelajaran sendiri di luar kelas. Reward juga bisa dikatakan sebagai motivasi yang diberikan oleh guru kepada siswanya (Sardiman, 2007: 92).

Berdasarkan beberapa pendapat di atas, dapat disimpulkan bahwa reward adalah segala sesuatu yang berupa penghargaan yang menyenangkan perasaan yang diberiakan kepada siswa karena telah berperilaku baik, mendapat hasil atau telah berhasil melaksanakan tugas yang diberikan guru dengan baik sehingga siswa senantiasa termotivasi untuk mengulang perbuatannya kembali. Diharapkan dari pemberian reward tersebut muncul keinginan dari di anak untuk lebih semangat belajar yang tumbuh dari dalam diri siswa sendiri

Punishment berasal dari Bahasa Inggris yang artinya hukuman. Menurut Baharuddin (2010:74), hukuman adalah menghadirkan atau memberikan sebuah situasi yang ingin dihindari untuk menurunkan tingkah laku. Mengenai hukuman itu, ada beberapa pandangan filsafat atau kepercayaan yang menganggap bahwa hidup ini termasuk sebagai suatu hukuman, karena kehidupan ini identik dengan penderitaan. Pandangan hidup yang demikian menganjurkan agar manusia menghindari diri dari hukuman atau penderitaan yang ada di dalam kehidupan ini.

Hukuman merupakan suatu tindakan yang kurang menyenangkan, yaitu berupa penderitaan yang diberikan kepada siswa atau anak secara sadar dan sengaja, sehingga siswa atau anak tidak mengulagi kesalahannya lagi. Hukuman diberikan sebagai akibat dari pelanggaran, kejahatan, atau kesalahan yang dilakukan siswa. Tidak seperti reward, hukuman atau punishment mengakibatkan penderitaan atau kedukaan bagi anak didik yang menerimanya (Djamarah, 2010:196).

Punishment atau hukuman menurut Ahmadi dan Uhbyati (dalam Yanuar, 2012:16) adalah suatu perbuatan, di mana kita secara sadar dan sengaja, menjatuhkan nestapa kepada orang lain, yang mana baik dari segi kejasmanian maupun kerohanian, orang lain tersebut mempunyai kelemahan jika

dibandingkan dengan diri kita.

Dari beberapa pendapat yang diutarakan oleh para ahli dapat disimpukan bahwa punishment atau hukuman adalah suatu tindakan kurang menyenangkan yang dilakukan terhadap seseorang secara sadar dan sengaja untuk menurunkan atau mengurangi terjadinya pelanggaran atau kesalahan. Punishment juga dapat 


$\begin{array}{ll}\text { Volume } & : 04 \\ \text { Nomor } & : 02 \\ \text { Bulan } & : \text { Mei } \\ \text { Tahun } & : 2018 \\ \text { http } & : / / \text { jurnal.pps.ung.ac.id/index.php/AKSARA/index }\end{array}$

dikatakan sebagai penguat yang negatif, tetapi kalau hukuman itu diberikan secara tepat dan bijak bisa menjadi alat motivasi

Reward dan punishment merupakan dua bentuk metode dalam memotivasi seseorang untuk melakukan kebaikan dan meningkatkan prestasinya. Kedua metode ini sudah cukup lama dikenal dalam dunia kerja. Tidak hanya dalam dunia kerja, dalam dunia pendidikan pun kedua ini kerap kali digunakan. Penerapan reward dan punishment dalam dunia pendidikan dapat diterapkan sepanjang hal tersebut tidak bertentangan dengan tujuan pendidikan itu sendiri. Penerapan reward dan punishment juga tidak hanya diterapkan kepada siswa yang berprestasi atau yang melanggar tata-tertib, tetapi juga dapat diterapkan kepada guruguru agar mereka berdisiplin dalam mengajar untuk memenuhi tugas mereka memberikan pelajaran kepada siswanya.

\section{Metode Penelitian}

Penelitian ini dilaksanakan di SDN 03 Duhiadaa Kabupaten Pohuwato dengan jumlah 8 orang guru. Penelitian ini menggunakan model Penelitian Tindakan Sekolah (PTS) yang dilaksanakan dalam dua siklus. Penelitian dilakukan untuk memperbaiki disiplin guru dalam kehadiran mengajar di kelas.Teknik pengumpulan data dari penelitian tindakan sekolah ini adalah melalui data kualitatif yang diperoleh dari observasi (pengamatan) maupun wawancara.

1. Observasi atau pengamatan

Observasi digunakan untuk melengkapi data dari wawancara dan pengumpulan dokumentasi, terutama dalam lingkup masalah penelitian, antara lain mengamati impelementasi kebijakan yang berkaitan dengan kedisiplinan guru dalam kehadiran dikelas pada kegiatan belajar mengajar.

2. Wawancara

Teknik ini digunakan untuk mendapatkan data dari informan secara langsung. Dalam melakukan wawancara dipergunakan pedoman wawancara yang terbuka.

3. Pengumpulan data sekunder

Teknik ini digunakan untuk mengumpul data sekunder melalui dokumen - dokumen tertulis yang diyakini integritasnya karena mengambil dari berbagai sumber yang relevan dengan penelitian. Pengambilan sumber yang bersifat sekunder ini dapat diperoleh dari hasil dialog bersama kolaborator, data base sekolah, dan lain - lain. Instrumen penelitian yang digunakan instrumen observasi menggunakan lembar observasi perilaku guru, instrumen wawancara berupa lembar wawancara yang telah disusun berupa daftar pertanyaan dalam penelitian tindakan sekolah ini (Arikunto,2002) antara lain adalah (1) skala penilaian, dan (2) lembar pengamatan. Analisa data yang digunakan dalam penelitian ini adalah analisa data kualitatif yang bersumber dari data primer maupun empiris. Melalui analisa data ini, dapat diketahui ada tidaknya peningkatan kedisiplinan guru dalam kehadiran dikelas melalui pemberian reward dan punishment yang merupakan fokus dari penelitian tindakan sekolah ini 


$\begin{array}{ll}\text { Volume } & : 04 \\ \text { Nomor } & : 02 \\ \text { Bulan } & : \text { Mei } \\ \text { Tahun } & : 2018 \\ \text { http } & : / / \text { jurnal.pps.ung.ac.id/index.php/AKSARA/index }\end{array}$

\section{Hasil Penelitian}

\section{Siklus 1}

\section{Perencanaan}

Perencanaan adalah langkah awal yang dilakukan oleh penulis saat akan memulai tindakan. Agar perencanaan mudah dipahami dan dilaksanakan oleh penulis yang akan melakukan tindakan, maka penulis membuat rencana tindakan sebagai berikut :

a) Merumusan masalah yang akan dicari solusinya. Dalam penelitian ini masalah yang akan dicari solusinya adalah masih banyaknya guru yang kurang disiplin dalam kehadiran dikelas pada proses belajar mengajar.

b) Merumusan tujuan penyelesaian masalah/tujuan menghadapi tantangan/tujuan melakukan inovasi/tindakan. Dalam penelitian ini penulis mengambil rencana untuk melakukan tindakan memberikan Reward dan Punishment kepada guruguru untuk meningkatkan kedisiplinan guru dalam melaksanakan tugas dikelas pada proses belajar mengajar.

c) Merumusan indikator keberhasilan penerapan Reward dan Punishment dalam meningkatkan disiplin guru dalam melaksanakan tugas dikelas. Indikator keberhasilan penerapan tindakan ini penulis tetapkan sebesar $75 \%$, artinya tindakan ini dinyatakan berhasil bila $75 \%$ guru tidak terlambat masuk kelas dalam proses pembelajaran.

d) Merumusan langkah-langkah kegiatan penyelesaian masalah/kegiatan menghadapi tantangan/kegiatan melakukan tindakan.

Langkah-langkah yang diambil penulis dalam melakukan tindakan antara lain adalah melakukan sosialisasi kepada para guru mengenai penelitian yang akan dilaksanakan, serta menyampaikan tujuan dari penerapan tindakan yang dilakukan oleh penulis.

Kepada para guru disampaikan mengenai penerapan Reward dan Punishment yang akan diterapkan dalam penelitian ini. Pada siklus pertama ini, akan dipampang/ditempel diruang guru, maupun diruang TU, peringkat nama-nama guru yang paling rendah tingkat keterlambatan masuk kelasnya sampai yang paling tinggi tingkat keterlambatannya.

e) Mengidentifikasi warga sekolah dan atau pihak-pihak terkait lainnya yang terlibat dalam penyelesaian masalah/menghadapi tantangan/melakukan tindakan. Penulis melakukan identifikasi siapa saja yang dilibatkan dalam penelitian ini. Pihak-pihak yang dilibatkan dalam penelitian ini adalah : guru, guru piket, TU, dan siswa.

f) Mengidentifikasi metode pengumpulan data yang akan digunakan

Metode pengumpulan data yang diambil oleh penulis merupakan data kualitatif melalui observasi, pengamatan serta wawancara kepada siswa mengenai kehadiran guru dikelas pada kegiatan belajar mengajar.

g) Penyusunan instrumen pengamatan dan evaluasi.

Dalam pengambilan data, penulis menggunakan instrument berupa lembar observasi/pengamatan, skala penilaian serta angket yang disebarkan kepada siswa, untuk mengetahui penilaian dari siswa mengenai tingkat kehadiran guru dikelas dalam proses kegiatan belajar mengajar. 


$\begin{array}{ll}\text { Volume } & : 04 \\ \text { Nomor } & : 02 \\ \text { Bulan } & : \text { Mei } \\ \text { Tahun } & : 2018 \\ \text { http } & : / / \text { jurnal.pps.ung.ac.id/index.php/AKSARA/index }\end{array}$

h) Mengidenifikasi fasilitas yang diperlukan.

Fasilitas atau alat bantu yang digunakan dalam penelitian ini antara lain : kertas (lembar pengamatan), alat tulis berupa balpoin, serta jam dinding yang ada disetiap kelas, serta rekap jumlah kehadiran dari setiap guru.

\section{Pelaksanaan}

Pelaksanaan penelitian tindakan sekolah ini dilaksanakan melalui beberapa kegiatan, antara lain:

a) Menyebarkan lembar pengamatan kepada setiap Ketua Kelas atau Sekretaris kelas sebanyak 6 set, sesuai dengan banyaknya jumlah rombongan belajar di SDN 03 Duhiadaa. Dalam lembar pengamatan itu, telah dibuat daftar guru yang mengajar dikelas itu setiap jam dan diberi kolom jam masuk kelas serta jam keluar kelas.

b) Berkoordinasi dengan petugas piket yang setiap hari terdiri dari 2 orang petugas, yaitu dari guru yang tidak mempunyai jam mengajar pada hari itu dan satu orang dari tata usaha. Petugas piket akan mengedarkan daftar hadir guru dikelas yang telah dibuat agar dapat melihat tingkat kehadiran guru disetiap kelas dan disetiap pergantian jam pelajaran. Guru yang terlambat lebih dari 15 menit, dianggap tidak hadir dan diberi tanda silang.

c) Setelah selesai jam pelajaran, dilakukan rekapitulasi dari hasil pengamatan, baik dari guru piket, dari siswa maupun dari penulis.

d) Kegiatan tersebut dilakukan terus setiap hari kepada setiap guru selama satu minggu (satu siklus).

\section{Pengamatan dan Evaluasi}

Pengamatan atau observasi dilakukan oleh peneliti dengan menggunakan lembar observasi selama satu minggu (satu siklus), untuk semua guru yang berjumlah 8 orang. Selama pengamatan peneliti dibantu atau berkolaborasi dengan guru piket. Pengamatan oleh peneliti meliputi : (a) Kehadiran guru dikelas (b) Tingkat keterlambatan guru masuk kelas (c) Waktu meninggalkan kelas setelah selesai pelajaran

Peneliti juga melakukan penilaian dari hasil lembar observasi yang dibagikan kepada pengurus kelas untuk mengamati kehadiran guru dikelas. Dari hasil pengamatan serta rekap dari tingkat kehadiran guru dikelas pada proses belajar mengajar dapat dilihat pada tabel berikut :

\begin{tabular}{|c|c|c|}
\hline \multicolumn{3}{|c|}{$\begin{array}{l}\text { REKAPITULASI TINGKAT KETERLAMBATAN } \\
\text { GURU PADA KEHADIRAN DIKELAS }\end{array}$} \\
\hline \multicolumn{3}{|c|}{ Waktu Keterlambatan / Jumlah Prosentase } \\
\hline Kurang dari 10 menit & 10 menit s.d 15 menit & Lebih dari 15 menit \\
\hline 2 & 3 & 3 \\
\hline $25 \%$ & $37,50 \%$ & $37,50 \%$ \\
\hline
\end{tabular}




$\begin{array}{ll}\text { Volume } & : 04 \\ \text { Nomor } & : 02 \\ \text { Bulan } & : \text { Mei } \\ \text { Tahun } & : 2018 \\ \text { http } & : / / \text { jurnal.pps.ung.ac.id/index.php/AKSARA/index }\end{array}$

Dari data diatas dapat ditarik kesimpulan bahwa tingkat keterlambatan guru masuk kelas antar 10 mniet sampai dengan lebih dari 15 menit pada proses kegiatan belajar mengajar masih tinggi yaitu 6 orang atau $75 \%$. Berdasarkan indicator yang telah ditetapkan bahwa keberhasilan tindakan ini adalah 75\%, atau bila $75 \%$ guru tidak terlambat lebih dari 10 menit. Jadi peneliti berkesimpulan harus diadakan penelitian atau tindakan lagi pada siklus berikutnya atau siklus kedua.

\section{Refleksi}

Setelah selesai satu siklus maka diadakan refleksi mengenai kelemahan atau kekurangan dari pelaksanaan tindakan pada siklus pertama. Refleksi dilaksanakan bersama-sama kolaborator untuk menentukan tindakan perbaikan pada siklus berikutnya. Dari hasil refleksi dapat diambil suatu kesimpulan bahwa perlu penerapan Reward dan Punishment yang lebih tegas lagi daripada siklus pertama.

\section{Siklus 2}

\section{Perencanaan}

Dari hasil refleksi pada siklus pertama, peneliti merencanakan untuk melakukan tindakan Reward dan Punishment yang lebih tegas dibandingkan dengan siklus pertama. Peneliti merencanakan untuk mengumumkan hasil observasi mengenai tingkat keterlambatan guru masuk kelas dalam proses belajar mengajar, pada kegiatan upacara bendera hari Senin. Hal ini terlebih dahulu disosialisasikan kepada semua guru pada saat refleksi siklus pertama.

\section{Pelaksanaan}

Pelaksanaan penelitian tindakan sekolah pada siklus yang kedua ini dilaksanakan melalui beberapa kegiatan, antara lain :

a) Menyebarkan lembar pengamatan kepada setiap Ketua Kelas atau Sekretaris kelas sebanyak 6 set, sesuai dengan banyaknya jumlah rombongan belajar. Dalam lembar pengamatan itu, telah dibuat daftar guru yang mengajar dikelas itu setiap jam dan diberi kolom jam masuk kelas serta jam keluar kelas.

b) Berkoordinasi dengan petugas piket yang setiap hari terdiri dari 2 orang petugas, yaitu dari guru yang tidak mempunyai jam mengajar pada hari itu dan satu orang dari tata usaha. Petugas piket akan mengedarkan daftar hadir guru dikelas yang telah dibuat agar dapat melihat tingkat kehadiran guru disetiap kelas dan disetiap pergantian jam pelajaran. Guru yang terlambat lebih dari 15 menit, dianggap tidak hadir dan diberi tanda silang.

c) Setelah selesai jam pelajaran, dilakukan rekapitulasi dari hasil pengamatan, baik dari guru piket, dari siswa maupun dari penulis. Kegiatan tersebut dilakukan terus setiap hari kepada setiap guru selama satu minggu (satu siklus) pada siklus kedua

\section{Pengamatan dan Evaluasi}

Pengamatan atau observasi dilakukan oleh peneliti dengan menggunakan lembar observasi selama satu minggu (satu siklus), untuk semua guru yang berjumlah 8 orang. Selama pengamatan peneliti dibantu atau berkolaborasi dengan guru piket. Pengamatan oleh peneliti meliputi : a) Kehadiran guru dikelas, b) 


$\begin{array}{ll}\text { Volume } & : 04 \\ \text { Nomor } & : 02 \\ \text { Bulan } & : \text { Mei } \\ \text { Tahun } & : 2018 \\ \text { http } & : / / \text { jurnal.pps.ung.ac.id/index.php/AKSARA/index }\end{array}$

Tingkat keterlambatan guru masuk kelas, c) Waktu meninggalkan kelas setelah selesai pelajaran

Peneliti juga melakukan penilaian dari hasil lembar observasi yang dibagikan kepada pengurus kelas untuk mengamati kehadiran guru dikelas. Dari hasil pengamatan serta rekap dari tingkat kehadiran guru dikelas pada proses belajar mengajar pada siklus kedua dapat dilihat pada tabel berikut:

REKAPITULASI TINGKAT KETERLAMBATAN

GURU PADA KEHADIRAN DIKELAS

SIKLUS II

\begin{tabular}{|c|c|c|}
\hline \multicolumn{3}{|c|}{ Waktu Keterlambatan / Jumlah Prosentase } \\
\hline Kurang dari 10 menit & 10 menit s.d 15 menit & Lebih dari 15 menit \\
\hline 6 & 2 & 0 \\
\hline $75 \%$ & $25 \%$ & $0,00 \%$ \\
\hline
\end{tabular}

Dari hasil rekapitulasi tingkat keterlambatan guru dikelas pada proses pembelajaran diperoleh data, sebanyak 6 orang guru terlambat masuk kelas kurang dari 10 menit, 2 orang guru terlambat masuk kelas 10 menit sampai dengan 15 menit, dan tidak ada satu orang pun guru yang terlambat masuk kelas lebih dari 15 menit.

\section{Refleksi}

Dari hasil observasi pada siklus pertama dan siklus kedua dapat dilihat ada penurunan tingkat keterlambatan guru dikelas pada kegiatan belajar mengajar, atau terdapat peningkatan kehadiran guru dikelas. Sehingga, peneliti mengambil kesimpulan bahwa tindakan yang dilaksanakan pada siklus kedua dinyatakan berhasil, karena terdapat $75 \%$ guru yang terlambat kurang dari 10 menit, atau sesuia dengan target yang telah ditentukan.

\section{Pembahasan}

Penelitian ini berawal dari fakta dilapangan yang sering di jumpai disekolah adalah kurang disiplinnya guru, terutama masalah disiplin guru masuk kedalam kelas pada saat kegiatan pembelajaran dikelas seperti yang terjadi pada guru SDN 03 Duhiadaa. Dari hasi penelitian ini di ketahui bahwa tindakan yang dilakukan selama dua siklus menunjukkan adanya peningkatan tingkat kedisiplinan guru masuk kelas atau dalam menjalankan tugasnya.

Pada siklus I persentase tingkat keterlambatan guru masuk kelas adalah 75\% atau 6 orang dan indikator yang telah ditetapkan bahwa keberhasilan tindakan ini adalah $75 \%$, atau bila $75 \%$ guru tidak terlambat lebih dari 10 menit. Pada siklus II persentase tingkat keterlambatan guru masuk kelas kurang dari 10 Menit adalah sebesar $25 \%$ atau 2 orang guru dan indikator yang telah ditetapkan bahwa keberhasilan tindakan ini adalah $75 \%$, atau bila $75 \%$ guru tidak terlambat lebih dari 10 menit jadi pada siklus II ini indicator yang di tetapkan telah tercapai.

Berdasarkan analisis data, dari penelitian ini dapat ditarik kesimpulan bahwa penerapan Reward dan Punishment efektif untuk meningkatkan disiplin kehadiran guru dikelas pada kegiatan belajar mengajar. Data yang diperoleh 


$\begin{array}{ll}\text { Volume } & : 04 \\ \text { Nomor } & : 02 \\ \text { Bulan } & : \text { Mei } \\ \text { Tahun } & : 2018 \\ \text { http } & : / / \text { jurnal.pps.ung.ac.id/index.php/AKSARA/index }\end{array}$

menunjukan bahwa setelah diadakan penerapan tindakan berupa Reward dan Punishment, guru yang terlambat lebih dari 15 menit adalah 0, dan guru yang terlambat kurang dari 10 menit sebanyak 6 orang guru. Penerapan Reward dan Punishment dapat meningkat disiplin guru hadir didalam kelas pada kegiatan belajar mengajar

\section{KESIMPULAN}

Berdasarkan analisis data, dari penelitian ini dapat ditarik kesimpulan bahwa penerapan Reward dan Punishment efektif untuk meningkatkan disiplin kehadiran guru dalam melaksanakan tugas dikelas pada kegiatan belajar mengajar. Data yang diperoleh menunjukan bahwa setelah diadakan penerapan tindakan berupa Reward dan Punishment, guru yang terlambat lebih dari 15 menit sudah tidak ada, dan guru yang terlambat kurang dari 10 menit sebanyak 6 orang guru. Penerapan Reward dan Punishment dapat meningkat disiplin guru hadir didalam kelas pada kegiatan belajar mengajar di sdn 03 Duhiadaa Kabupaten Pohuwato

\section{DAFTAR PUSTAKA}

Anwar Prabu Mangkunegara. (1994). Psikologi Perusahaan. Bandung:PT. Trigenda

Karya

Perusahaan.

(2000). Manajemen Sumber Daya Manusia

Bandung : Penerbit Remaja Rosdakarya.

Arikunto, S. (2002). Prosedur Penelitian Suatu Pendekatan Praktek. Jakarta : Rineka Cipta

Aunurrahman. (2009). Belajar dan Pembelajaran. Bandung:Alfabeta

Bambang Nugroho. (2006). Reward dan Punishment. Bulletin Cipta Karya Departemen Pekerjaan Umum Edisi No. 6/IV/Juni 2006

Departemen Pendidikan Nasional. (2003). Undang-undang Nomor 20 Tahun 2003

Tentang Sistem Pendidikan Nasional. Jakarta:Depdiknas

Hasibuan, Malayu. S.P. (2002). Managemen Sumber Daya Manusia. Jakarta : Bumi Aksara (2003). Managemen Sumber Daya Manusia. Jakarta : Bumi

Aksara

Hidayat, Sucherli. (1986). Peningkatan Produktivitas Organisasi dan Pegawai Negeri Sipil: Kasus Indonesia. Jakarta:Prisma

Megawangi, Ratna. (2007). Membangun SDM Indonesia Melalui Pendidikan Holistik

Berbasis Karakter. Jakarta:Indonesian Heritage Foundation

Riduwan,. 2003. Dasar-Dasar Statistika. Bandung : Alfabeta

Sanjaya, W. (2008). Kurikulum dan Pembelajaran. Teori dan Praktik Pengembangan

Kurikulum Tingkat Satuan Pendidikan (KTSP). Jakarta: Kencana Prenada Media

Group

Sastrohardiwiryo, Siswanto. (2003) Managemen Tenaga Kerja Indonesia. Jakarta : Bumi Aksara 